Jurnal Bosaparis: Pendidikan Kesejahteraan Keluarga

Volume 9, Nomor 3, November 2018

\title{
PENGEMBANGAN TATA RIAS FANTASI DENGAN SUMBER IDE MITOLOGI CHINA
}

\author{
Made Yunitari, I Gede Sudirtha, Made Diah Angendari \\ Jurusan Pendidikan Kesejahteraan Keluarga, Fakultas Teknik dan Kejuruan \\ Universitas Pendidikan Ganesha \\ Singaraja,Indonesia
}

e-mail : mayunita96@gmail.com,gede.sudirtha@undiksha.ac.id, diah.angendari@undiksha.ac.id

\begin{abstract}
ABSTRAK
Tujuan dari penelitian ini adalah untuk (1) mendeskripsikan proses pengembangan tata rias fantasi; (2) menerangkan hasil akhir dari pengembangan tata rias fantasi. Jenis penelitian yang digunakan adalah research and development dengan model ADDIE. Subyek dari penelitian ini yaitu 2 orang ahli isi instrumen dan 2 orang ahli produk yang akan menilai hasil produk tata rias fantasi dengan sumber ide mitologi China. Penelitian menggunakan analisis kualitatif dan kuantitatif. Hasil penelitian yang diperoleh meliputi (1) Proses pengembangan tata rias fantasi dengan sumber ide mitologi China dimulai dari tahap analisis, desain, pengembangan terdiri dari persiapan dan pelaksanaan, implementasi dan evaluasi berupa saran para ahli produk (2) Hasil akhir berupa tata rias fantasi meliputi tata rias wajah, penataan rambut dan body painting yang dikembangkan dari sumber ide mitologi China. Hasil penilaian yang didapatkan dari para ahli produk yakni tingkat pencapaian dari validitas produk adalah $94.99 \%$ dengan kualifikasi produk dapat dikatakan sangat baik.
\end{abstract}

Kata kunci : Mitologi China, Pengembangan, Sumber Ide , Tata Rias Fantasi

\section{ABSTRACT}

The study arrived at (1) describing the process of developing fantasy makeup; (2) explaining the final result of developing fantasy makeup. The type of this qualitative and quantitative study was research and development with ADDIE research model. The subject of this study were 2 instrument content experts and 2 product experts who assessed the result of fantasy makeup products with the source of Chinese mythological idea. The study reveals (1) The process of developing fantasy makeup with the source of Chinese mythological idea starting from the stage of analysis, design, development, consisting of preparation and implementation, implementation and evaluation in the form of advice from product experts (2) The final results in the form of fantasy makeup include facial makeup, hair styling and body painting which are developed from the source of Chinese mythological idea. The obtained assesssment result from the product experts is the level of achievement of product validity is $94.99 \%$ which means that the product is categorized as a very good product.

Keywords: Chinese Mythology, Development, Idea Source, Fantasy Makeup 


\section{PENDAHULUAN}

$\begin{array}{lrr}\text { Asia merupakan } & \text { benua } \\ \text { terbesar dan paling } & \text { padat } \\ \text { penduduknya } & \text { di } & \text { dunia }\end{array}$

(Wikipedia,2018). Banyak negaranegara yang sudah berkembang dan maju di benua Asia mulai dari perekonomiannya hingga teknologinya. Selain itu, benua Asia banyak memiliki negara-negara yang sangat berpengaruh di dunia contohnya negara di Asia Timur seperti Jepang, dan Korea Selatan, negara di Timur Tengah seperti Arab Saudi dan Qatar, serta negara dengan budaya peradaban tinggi seperti China.

China atau yang kerap dikenal dengan Republik Rakyat China (RRC) merupakan salah satu negara yang berada di Asia Timur dimana ibu kota dari China adalah Beijing. Negara China merupakan salah satu negara di Asia yang bisa dikatakan maju dilihat dari segi ekonomi maupun teknologinya.

Sumber terbesar mitologi China adalah catatan tertulis berupa literatur. Seperti halnya mitologi dunia lainnya, mitologi China juga memiliki keunikan tersendiri. Salah satu ciri khas literatur mitologi China adalah daya imajinasi yang tinggi. Isi dari mitologi China sangat banyak karena merupakan cerita turun temurun dengan kurun waktu lebih dari 2.000 tahun. Yuan Ke, seorang peneliti mitologi China membagi jenis mitologi China menjadi 3 macam, yaitu: mitos, legenda dan dewa-dewi. Salah satu mitos yang terkenal dalam mitologi China adalah mitos dari mahkluk mistis yang dipercaya membawa keberuntungan dan kemakmuran seperti naga, burung phoenix, pixiu, qilin serta jenis-jenis makhluk mistis lainnya (Wikipedia,2018).

Dalam mitologi China, naga dan burung phoenix merupakan simbol dari yin dan yang juga kerap dikaitkan dengan kaisar dan permaisuri kerjaan China. Sejak masa Dinasti Han, phoenix bersama naga kerap menjadi ragam hias disetiap istana yang dibangun pada masa itu. Dalam sejarah China masa itu, phoenix menjadi simbol sanjungan bagi penguasa yang berhasil dalam memimpin negara dengan damai. Pada perkembangan selanjutnya, phoenix pun menjadi lambang agung yang hanya dapat dikenakan oleh permaisuri kaisar China. Selama berabad silam, satwa mitologi ini menjadi satu-satunya motif resmi kerajaan yang digunakan sebagai sulaman jubah permaisuri, mahkota, hiasan rambut, tusuk konde dan aksesoris mewah lainnya. Semuanya hanya boleh dikenakan oleh sang ratu (Silvia Agmasari:2014:2)

Naga dalam mitologi China merupakan makhluk bernama Liong atau Lung yang umumnya diterjemahkan ke dalam bahasa Indonesia dengan istilah naga. Mahkluk ini digambarkan sebagai ular berukuran raksasa, legkap dengan tanduk, sungut, dan cakar (Wikipedia,2018). Sedangkan untuk burung phoenix kerap digambarkan memiliki kepala seperti burung pelikan, berleher seperti ular, berekor sisik ikan, bermahkota burung merak, bertulang punggung mirip naga, berkulit sekeras kurakura. Sementara bulunya memiliki lima warna lambang kebajikan, ekornya dapat menghasilkan suara musik jika bergerak dan bersinggungan dengan angin, dan ia lebih banyak bersembunyi, hanya muncul pada saat sebuah negara mengalami malapetaka.

Selain terkenal akan mitos makhluk mistisnya, mitologi China juga tidak lepas dari kisah dewadewinya yang penuh dengan welas asih dimana salah satu dewi yang terkenal adalah Dewi Kwan Im . Beliau kerap digambarkan sebagai dewi yang selalu menolong 
masyarakat yang kesusahan yang memiliki singgasana berbentuk teratai. Teratai dalam mitologi China sering kali diartika sebagai simbol kasih sayang dan cinta. Kesatuan antara benih, bunga mekar dan kuncup teratai merupakan simbol masa lalu, sekarang dan masa yang akan datang. Selain menjadi smbol kasih sayang dan cinta, bunga teratai juga merupakan simbol dari kesetiaan dan ketabahan dimana bunyi nama bunga teratai dalam bahasa Mandarin adalah he lian yang bermakna perdamaian dan keberlanjutan. (Silvita Agmasari, 2014)

Tata rias wajah fantasi adalah tata rias yang menggunakan inspriasi atau ide dari sang penata rias untuk mewujudkan suatu tatanan rias dan rambut maupun body painting sesuai dengan tema yang diangkat. Menurut Eko Santosa, dkk (2013:275) tata rias fantasi dikenal juga dengan istilah tata rias karakter khusus. Disebut tata rias karakter khusus karena menampilkan wujud rekaan dengan mengubah wajah tidak realistik. Tata rias fantasi menggambarkan tokohtokoh yang tidak riil keberadaannya dan lahir berdasarkan daya khayal semata. Misalnya wujud seorang ratu cantik, putri bunga, putri dewi laut, putri duyung atau lainnya. Yang harus diperhatikan didalam melakukan tata rias fantasi adalah tema, rias wajah dan rambut, rias raga/body painting, busana, dan perlengkapan busana /ornament laksesoris.

Berdasarkan hasil pengamatan penulis, sejauh ini tata rias fantasi yang sudah dibuat atau dikembangkan hanya menggunakan sumber ide dari flora, fauna maupun dongeng-dongeng dari kisah putri raja dan belum ada yang mengambil pengembangan tata rias fantasi dengan sumber ide mitologi China. Sehingga hasil akhir dari pengembangan tata rias fantasi dengan sumber ide mitologi China masih belum ada atau belum ditemukan. Berdasarkan latar belakang di atas maka penulis akan melakukan pengembangan dengan menggunakan model ADDIE (Analysis, Design, Development, Implementation, Evaluasi). Pengembangan memiliki banyak model dengan tahap yang berbedabeda, penulis menggunakan model ADDIE dikarenakan model ADDIE memiliki tahap-tahap yang lebih simpel dan mudah untuk diterapkan mengingat jenis pengembangan produk berupa tata rias fantasi. Penulis akan melakukan pengembangan berupa tata rias fantasi meliputi tata rias wajah, penataan rambut, dan body painting serta busana yang akan dibuat sebagai penunjang dari tata rias fantasi tersebut. Dalam pengembangan tata rias fantasi yang akan dilakukan penulis menggunakan sumber ide mitologi China karena mitologi China sudah berkembang menjadi kepercayaan tradisional China dan sebagian masyarakatnya percaya bahwa isi mitologi China tersebut adalah catatan sejarah yang nyata karena memiliki mitos dan legenda pembentukkan tradisi atau sejarah China. Selain itu alasan mengapa penulis menggunakan sumber ide dari mitologi China karena penulis memiliki rasa ketertarikan akan budaya China khususnya mitologi China dimana penulis menganggap mitologi China memiliki banyak kisah-kisah yang sangat melegenda sehingga menjadikan ciri khas dari negara China itu sendiri. Mulai dari naga dan burung phoenix yang dilambangkan sebagai kaisar dan permaisuri mereka hingga bunga teratai yang memiliki makna kasih sayang dan cinta yang kerap disandingnya dengan dewa-dewi 
mitologi China yang memiliki rasa welas asih. Juga mitologi China tersebut khususnya makhluk mistisnya sudah banyak dijadikan atau dikembangkan menjadi sebuah karya seni mulai dari seni lukis hingga arsitektur sehingga penulis ingin mengembangkan sumber ide tersebut menjadi sebuah tata rias fantasi karena mitologi China bukan hanya bisa diterapkan atau dikembangkan menjadi seni lukis atau arsitektur saja melainkan dapat menjadi sumber ide dalam membuat tata rias fantasi. Maka dari itu penelitian ini menggambil beberap permasalahan yaitu : (a) Bagaimana proses pengembangan tata rias fantasi dengan sumber ide mitologi China?, (b) Bagaimana hasil dari pengembangan tata rias fantasi dengan sumber ide mitologi China?

\section{METODE PENELITIAN}

Penelitian pengembangan atau Research and Development $(R \& D)$ adalah cara-cara yang mengatur prosedur penelitian ilmiah pada umumnya sekaligus pelaksanaannya terhadap masingmasing ilmu secara khusus (Nyoman,2010:41). Sedangkan menurut Sugiyono (2011:3) metode penelitian diartikan sebagai cara ilmiah untuk mendapatkan data dengan tujuan dan kegunaan tertentu. Penelitian pengembangan yang dilakukan oleh penulis menggunakan model pengembangan ADDIE. Model pengembangan ADDIE dikembangkan oleh Reiser dan Mollenda.

Model pengembangan ini terdiri atas lima langkah, yaitu 1) analisis(analyze), 2) perancangan (design), 3) pengembangan (development), 4) impelentasi (implementation), 5) evaluasi (evaluation).

Subjek penelitian dalam penelitian ini adalah Subyek uji validasi produk hasil penelitian pengembangan tata rias fantasi merupakan 2 orang ahli dalam bidang tata rias fantasi.

Adapun teknik pengumpulan data yang digunakan saat penelitian adalah teknik pengumpulan data kuesioner.

\section{HASIL PENELITIAN DAN PEMBAHASAN}

Dalam penelitian ini disajikan hasil dan pembahasan tentang dua hal pokok yaitu : (a) proses pengembangan tata rias fantasi dengan sumber ide mitologi China, (b) hasil dari pengembangan tata rias fantasi dengan sumber ide mitologi China, sebagai berikut :

\section{Proses Pengembangan Tata Rias Fantasi Dengan Sumber Ide Mitologi China}

Berdasarkan langkah dalam penelitian pengembangan yang menggunakan model pengembangan ADDIE, maka didapatkan hasil sebagai berikut :

1. Tahap Pertama (Analysis)

Pada tahap pertama dari model ADDIE yakni adalah analisis (analysis) dimana hal yang peneliti lakukan dalam pengembangan tata rias fantasi dengan sumber ide mitologi China adalah menentukan mitologi China sebagai sumber ide yang akan digunakan untuk tata rias fantasi. Setelah itu, penulis menganalisis karakteristik dari mitologi China. Selanjutnya, penulis menganalisis karakteristik dalam tata rias fantasi dimana nantinya akan digabungkan dengan mitologi China untuk menciptakan satu kesatuan.

Berdasarkan hasil analisis karakteristik mitologi China maka sumber ide yang digunakan adalah

a) Naga dan Burung Phoenix Sumber ide yang digunakan yakni naga dan burung phoenix dimana berdasarkan kajian teori yang sudah 
dipaparkan oleh penulis naga dan burung phoenix merupakan lambang dari kaisar serta permaisuri dari China. Naga digambarkan sebagai ular berukuran raksasa, lengkap dengan tanduk dan cakar dimana hal yang membedakan naga China dengan naga lain adalah kumisnya yang panjang dan melingkar pada ujungnya. Sedangkan burung phoenix digambarkan memiliki kepala seperti burung pelikan, berleher seperti ular, berekor sisik ikan, bermahkota burung merak, bertulang punggung mirip naga, dan berkulit sekeras kura-kura.

Setelah menganalisis bentuk dan makna dari naga dan burung phoenix, maka sumber ide naga dan burung phoenix cocok untuk digunakan pada body painting pada bagian dada, punggung dan kaki karena penulis ingin menonjolkan simbol kaisar dan permaisuri China pada body painting. Selain itu, penulis juga menggunakan sumber ide burung phoenix pada aksesoris rambut dan busana yang digunakan

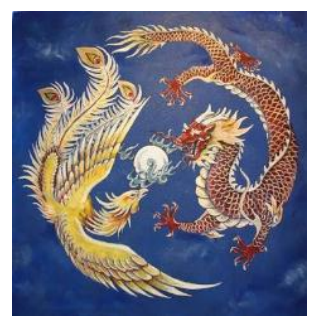

Gambar 1. Naga dan Burung

Phoenix

Sumber:

www.google.com/nagadanburungph oenix

b) Bunga Teratai

Selain menggunakan makhluk mistis mitologi, penulis juga menggunakan bunga teratai merah sebagai sumber ide. Bunga teratai merupakan singgasana Dewi Kwan Im yang merupakan salah satu dewa-dewi dalam mitologi China dimana bunga teratai merah disimbolkan sebagai rasa kasih sayang.
Berdasarkan hasil analisis bunga teratai yang merupakan singgasana dari dewi Kwan Im, penulis menggunakan sumber ide bunga teratai pada tata rias wajah, dan aksesoris rambut.

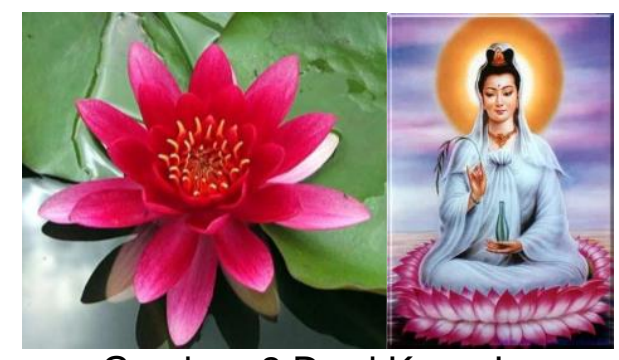

Gambar. 2 Dewi Kwan Im

Sumber:

www.google.com/dewikwanimdanter atai

2 Tahap Kedua ( Design)

Pada tahap yang kedua dari ADDIE yakni desain (design) dimana hal yang dilakukan oleh penulis dalam pengembangan tata rias fantasi dengan sumber ide mitologi China adalah mendesain tata rias fantasi mulai dari tata rias wajah, tata rias rambut dan body painting. Setelah melakukan analisis karakteristik dari mitologi China dan tata rias fantasi, maka penulis mendesain tata rias fantasi untuk mempermudah proses pengembangan tata rias fantasi dengan sumber ide mitologi China.

Berikut merupakan desain tata rias fantasi dengan sumber ide mitologi China mulai dari desain tata rias wajah, pentaan rambut, body painting dan busana.

a) Tata Rias Wajah

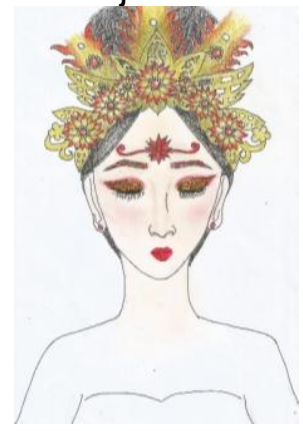




\section{Gambar. 3 Desain Tata Rias Wajah Fantasi \\ Sumber: Dokumentasi Pribadi}

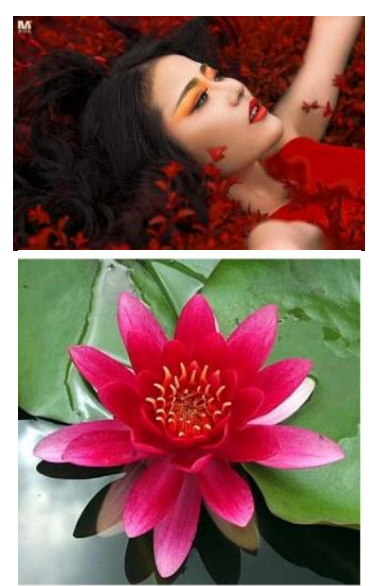

Gambar. 4 Sumber Ide Yang Digunakan Pada Tata Rias Wajah

Sumber: www.google.com

Dalam desain tata rias wajah fantasi yang sudah dibuat penulis menggunakan sumber ide mitologi China yakni dari teratai dimana teratai dilambangkan dengan kasih sayang. Selain menggunakan simbol teratai, penulis memadupadakan sumber ide dengan tren make up yang pernah ada di China dimana tren makeup tersebut merupakan makeup opera dengan bauran eyeshadow emas dan merah pada bagian kerung matanya memanjang hingga batas ujung alis. Selain itu, eyeshadow juga dibuat sedemikianrupa hingga menyerupai bentuk kelopak dari bunga teratai. Serta pada bagian dahi, penulis menambahkan face painting bunga teratai merah. Jadi, sumber ide bunga teratai terletak pada face painting dan bauran eyeshadow yang menyerupai kelopak bunga teratai dimana tata rias wajah yang digunakan mengacu pada tata rias opera China. b) Penataan Rambut
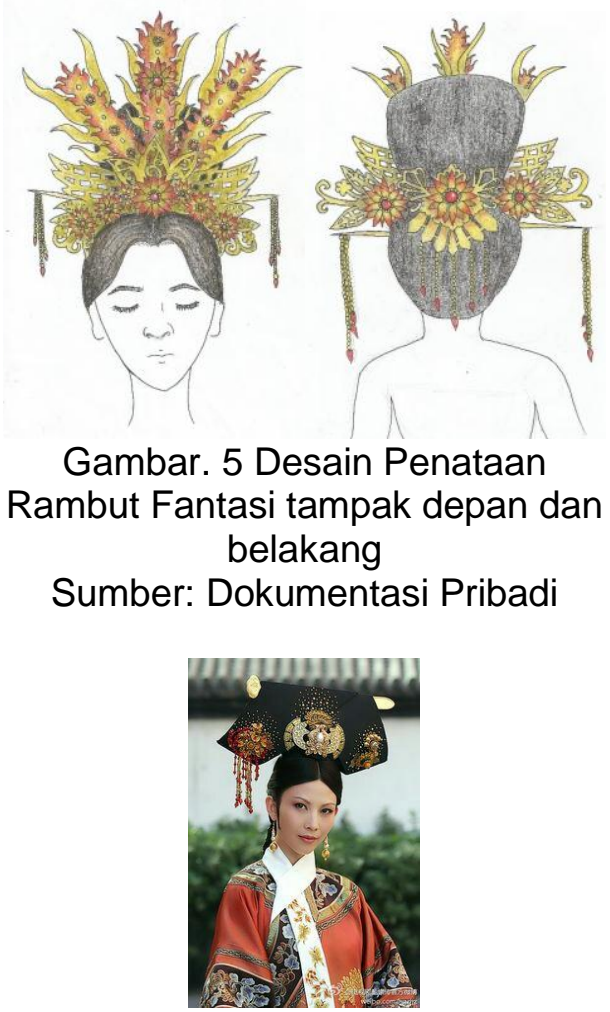

Gambar. 6 Sumber Ide Penataan

Rambut dan Aksesoris

Sumber: www.google.com

Desain penataan rambut yang telah di desain oleh penulis merupakan penataan rambut top style dimana top style pada umumnya digunakan dalam penataan fantasi. Untuk aksesoris yang digunakan pada desain merupakan aksesoris dengan sumber ide dari aksesoris kepala ba liang tou pada dinasti Han dengan aksen bunga teratai dan ekor dari burung phoenix pada bagian atas aksesoris dengan penambahan sulur-sulur seperti api. Dan untuk pelengkap aksesoris digunakan tusuk konde yang menjadi ciri khas dari wanita China. 
c) Body Painting

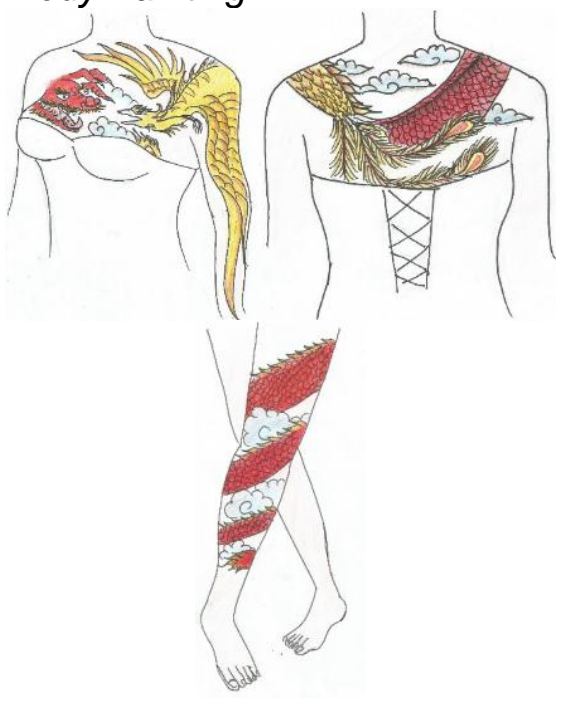

Gambar. 7 Body Painting pada bagian tubuh

Sumber: Dokumentasi Pribadi

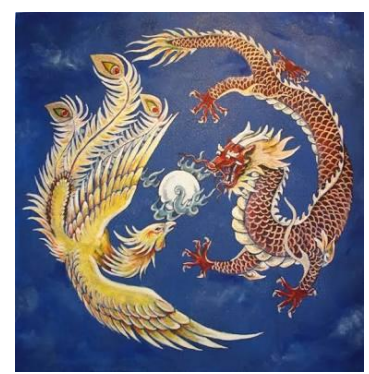

Gambar. 8 Sumber Ide Body Painting

Sumber: www.google.com

Desain body painting yang dibuat oleh penulis meliputi bagian dada hingga tangan kiri, punggung dan bagian kaki menggunakan sumber ide mitologi China yaitu naga dan burung phoenix yang merupakan simbol dari kaisar dan permaisuri China dimana pada bagian dada hingga tangan digunakan gambaran kepala naga serta kepala burung phoenix hingga sayap yang menyambung ke bagian tangan kiri. Pada bagian punggung digunakan gambar badan naga dan ekor burung phoenix. Dan pada bagian kaki kiri digunakan gambar ekor naga. Warna yang digunakan adalah merah untuk naga sedangkan kuning keemasan dengan sedikit warna merah untuk burung phoenix. Serta ditambahkan sedikit gambar awan untuk mengisi ruang yang kosong pada body painting.

d) Busana/Kostum

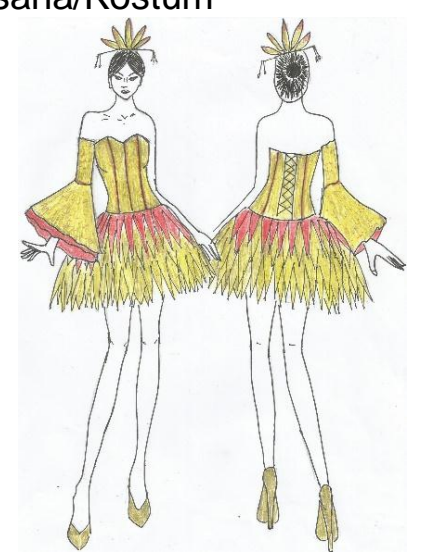

Gambar. 9 Busana Fantasi Sumber: Dokumentasi Pribadi

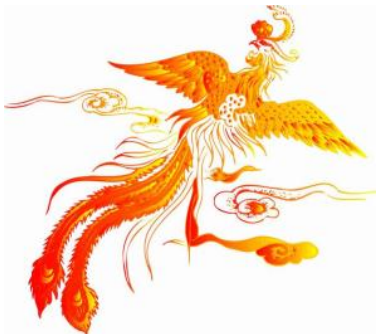

Gambar. 10 Sumber Ide Busana Sumber: www.google.com

Busana pada merupakan salah satu pelengkap serta aspek penunjang yang penting di dalam tata rias fantasi sehingga busana harus disesuaikan dengan sumber ide yang akan diwujudkan. Untuk busana, penulis menggunakan sumber ide dari burung phoenix dimana pada bagian rok diibaratkan dengan bulu-bulu burung phoenix yang berwarna kuning keemasan dengan sedikit aksen warna merah pada bagian atas rok dimana bahan yang digunakan pada rok adalah kain tile. Pada bagian badan, menggunakan bustier dengan tambahan korset. Bagian lengan 
menggunakan jenis lengan lonceng yang dikombinasi dengan lengan kerut pada bagian atas. Sepatu yang digunakan berwarna emas dengan menggunakan sepatu jenis high heels.

\section{Tahap Ketiga (Development)}

Tahap yang ketiga dari ADDIE adalah pengembangan (development). Pada tahap ini, penulis mengembangkan sebuah produk yang sebelumnya sudah didesain terlebih dahulu pada tahap kedua ADDIE. Dimana media yang digunakan untuk mengembangkan produk tersebut adalah seorang model yang nantinya akan dirias sesuai dengan desain yang telah dibuat dan tentunya sesuai dengan tema yakni mitologi China. Body painting pada model akan dilakukan pada bagian dada, punggung, tangan kiri dan kaki kiri dimana body painting juga dibuat sedemikian rupa sesuai dengan tema mitologi China. Dalam tahap pengembangan (development) penulis membagi dalam beberapa bagian diantaranya:

\section{a. Tahap Persiapan}

Sebelum memulai proses, pada tahap ini penulis mempersiapkan segala sesuatu yang dibutuhkan dan digunakan nanti, mulai dari mempersiapkan bahan, kosmetik, lenan dan aksesoris yang akan digunakan nantinya pada tahap persiapan semua disiapkan.

\section{b. Tahap Pelaksanaan}

Pada tahap pelaksanaan, penulis mulai melakukan tata rias fantasi dengan sumber ide mitologi China mulai dari proses merias wajah, menata rambut hingga body painting pada model yang sudah disiapkan.

Hasil Akhir Pengembangan Tata Rias Fantasi dengan Sumber Ide Mitologi China
Tata rias yang dihasilkan meliputi tata rias wajah, penataan rambut dan body painting. Tata rias wajah dikembangkan dari sumber ide teratai yang dipadukan dengan tren make up opera yang pernah ada di China. Pentaan rambut menggunakan penataan tipe top style dimana penataan tersebut umumnya digunakan untuk penataan fantasi, dengan aksesoris kepala yang dibuat menggunakan sumber ide dari bunga teratai yang dipadukan dengan penataan rambut bangsa Manchu "ba liang tou" dan ekor burung phoenix. Body painting dikembangkan dari sumber ide naga dan burung phoenix yang menjadi lambang dari kaisar dan permaisuri China. Selanjutnya untuk busana dikembangkan dari sumber ide burung phoenix dimana pada bagian rok terinspirasi dari bulu burung phoenix lalu pada bagian lengan menggunakan lengan lonceng dan lengan kerut. Berikut hasil akhir dari pengembangan tata rias fantasi dapat penulis lampirkan.

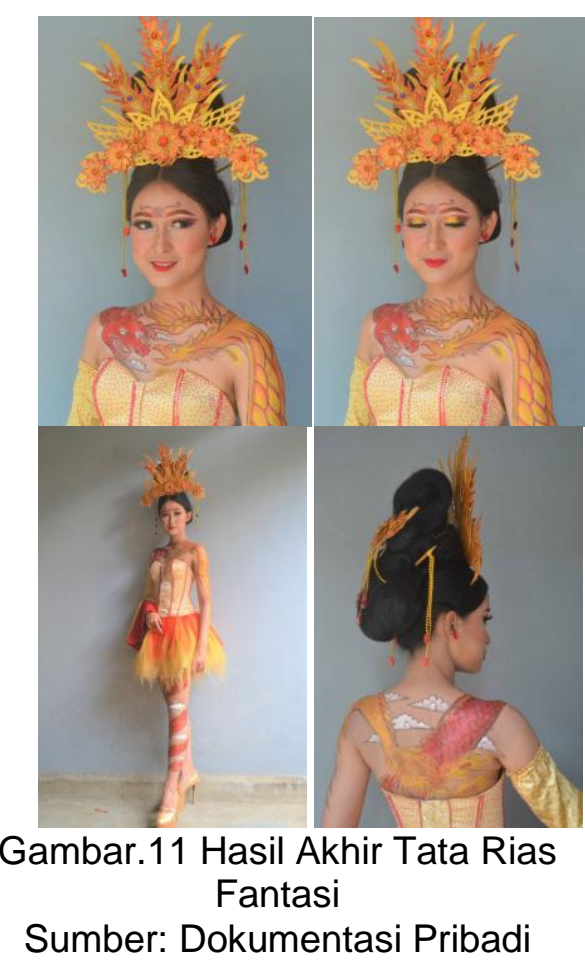


Bedasarkan hasil akhir pengembangan tata rias fantasi dengan sumber ide mitologi China yang sudah dilampirkan, pada tata rias fantasi tersebut dimana pada tata rias wajah menggunakan konsep tren make up opera yang sempat ada pada zaman kerajaan China dimana eyeshadow yang digunakan berwarna merah yang dibaurkan cukup panjang hingga batas alis dengan sentuhan face painting yang berbentuk teratai pada dahi model. Penataan rambut yang digunakan merupakan penataan model up style yang umumnya digunakan untuk penataan fantasi dimana tatanan rambut yang digunakan terinspirasi dari ba liang tou yang merupakan tatanan rambut dari bangsa Manchu namun dimodifikasi pada bagian aksesois rambut yang menggunakan sumber ide bunga teratai yang dipadukan dengan ekor burung phoenix. Untuk body painting/rias raga, digunakan sumber ide naga dan burung phoenix yang merupakan simbol dari kaisar dan permaisuri bangsa China dimana pada bagian depan digambarkan kepala naga dan burung phoenix, pada bagian punggung digambarkan badan naga dan burung phoenix, pada bagian tangan kanan merupaka sayap burung phoenix dan pada bagian kaki kanan digambarkan ekor naga yang terkesan melilit kaki model. Busana yang merupakan salah satu unsur pelengkap dari tata rias fantasi menggunakan sumber ide dari burung phoenix dimana rok pada busana diumpamakan helaian bulu burung phoenix dan pada bagian lengan digunakan lengan lonceng yang dikombinasikan dengan lengan kerut.

Berdasarkan pembahasan yang sudah disampaikan diatas, penelitian yang dilakukan oleh penulis menggunakan sumber ide mitologi China dimana dari mitologi
China tersebut digunakan mahkluk mistis diantaranya naga, burung phoenix dan bunga teratai. Naga dan burung phoenix dipilih menjadi sumber ide karena naga dan burung phoenix merupakan lambang dari seorang kaisar dan permaisuri China, selain itu naga dan burung phoenix merupakan simbol yin dan yang. Sedangkan bunga teratai dipilih menjadi sumber ide karena bunga teratai merupakan singgasana Dewi Kwan Im yang terkenal akan rasa welas asihnya dimana singgasana beliau yang merupakan bunga teratai memiliki makna rasa kasih sayang. Pengembangan yang dilakukan oleh penulis menggunakan model ADDIE dimana ADDIE memiliki 5 tahap diantaranya: analysis (analisis), desain (design), pengembangan (development), implementasi (implementation), evaluasi (evaluation). Pada tahap analisis, penulis menganalisis karakteristik mitologi China sehingga mendapatkan hasil naga, burung phoenix dan bunga teratai sebagai sumber ide yang akan digunakan. Tahap desain, penulis mendesain mulai dari tata rias wajah, penataan rambut, body painting, dan busana yang akan digunakan. Tahap pengembangan terdiri dari persiapan dan pelaksanaan. Tahap implementasi meliputi penilaian dari para ahli produk. Tahap evaluasi merupakan masukan-masuakan dan saran yang diberikan oleh ahli produk untuk penelitian yang sudah dilakukan oleh penulis. Hasil akhir dari pengembangan tata rias fantasi dengan sumber ide mitologi China yang sudah dilakukan oleh penulis dimana tata rias yang dihasilkan meliputi tata rias wajah, penataan rambut dan body painting.

Dari penelitian yang sudah dilakukan oleh penulis sama dengan penelitian yang sudah dilakukan oleh Marifani Fitri Arisa yang berjudul 
Pengembangan Tata Rias Tokoh Dalam Drama Sunan Panggung dimana penelitian yang dilakukan bertujuan untuk 1) menghasilkan desain tata rias tokoh "Sunan Panggung" dalam drama Sunan Panggung, 2) menghasilkan perwujudan bentuk tata rias tokoh "Sunan Panggung", 3) mengetahui hasil penilaian pakar terhadap bentuk tata rias tokoh "Sunan Panggung". Prosedur yang digunakan dalam penelitian ini adalah prosedur pengembangan karya seni menurut Gustami terdiri dari eksplorasi, perancangan, perwujudan, dan pengujian artistik. Hasil dari penelitian ini yaitu: 1) disain sunan panggung dengan karakter tokoh yang berwibawa, sabar, tanggung jawab, pemberani, rasa ingin tahu, dan keinginan berguru. 2) proses perwujudan tata rias meliputi : pembersihan wajah, pengaplikasian liquid latex, foundation, pemasangan kumis dan jenggot, pengaplikasian eye shadow, kerutan wajah, shading hidung, blush on, bedak, lisptik, dan efek uban pada kumis, jenggot, alis dan rambut. Tata rias yang dikembangkan dalam penelitian ini antara lain : pemilihan warna eye shadow, pemilihan warna bibir, efek kerutan dengan menggunakan liquid latex, pemasangan kumis dan jenggot, dan penataan rambut; dan 3) penilaian para pakar meliputi penilaian disain dan perwujudan disain. Hasil penilaian secara keseluruhan masing-masing mendapatkan kategori baik.

Perbedaan dari penelitian yang sudah dilakukan penulis dengan penelitian yang dilakukan oleh Marifani Fitri Arisa pada tahun 2014 terletak pada tata rias yang dikembangkan dimana Marifani Fitri Arisa mengembangkan tata rias tokoh sedangkan penulis mengembangkan tata rias fantasi. Perbedaan juga ditemukan pada prosedur yang digunakan dimana penulis menggunakan prosedur dari model ADDIE yang terdiri dari analisis, desain, development (pengembangan), implementasi, dan evaluasi sedangkan penelitian yang dilakukan oleh Marifani Fitri Arisa menggunakan prosedur pengembangan karya seni menurut Gustami dimana terdiri dari eksplorasi, perancangan, perwujudan, dan pengujian artistik.

\section{SIMPULAN DAN SARAN}

Berdasarkan hasil dari penelitian, maka kesimpulan yang dapat diambil dalam penelitian pengembangan dalam tata rias fantasi dengan sumber ide mitologi China adalah

Pengembangan tata rias fantasi dengan sumber ide mitologi China meliputi 5 tahap diantaranya analisis, desain, pengembangan (development), implementasi, evaluasi. Pada tahap implementasi penulis melakukan penilaian dimana menggunakan ahli isi dan ahli produk. Berdasarkan rekapitulasi penilaian ahli isi yang terdapat pada tabel 4.1 memperlihatkan bahwa dalam kriteria validitas isi instrumen pada tabel 3.5, maka dapat dipaparkan bahwa instrumen termasuk valid karena berada dalam rentangan kriteria derajat validitas sangat tinggi. Sedangkan untuk hasil dari ahli produk yang terdapat pada tabel 4.2 memperlihatkan bahwa dalam konvensi tingkat pencapaian produk yang terdapat pada tabel 3.6 maka dapat dipaparkan bahwa kualifikasi produk dapat dikatakan sangat baik dengan rerata $94.99 \%$

Hasil akhir yang didapatkan dari pegembangan tata rias fantasi dengan sumber ide mitologi China merupakan total look atau keseluruhan dari tata rias fantasi meliputi tata rias wajah, penataan rambut, dan body painting. Tata rias fantasi tersebut dikembangkan 
menggunakan sumber ide mitologi China meliputi naga, burung phoenix dan bunga teratai dimana naga dan burung phoenix merupakan lambang seorang kaisar dan permaisuri China sedangkan untuk bunga teratai merupakan lambang dari rasa kasih sayang. Berdasarkan hasil yang diperoleh dari penelitian pengembangan tata rias fantasi dengan sumber ide mitologi China, maka penulis dapat memberikan saran untuk lebih mengembangkan dan mengeksplor tema atau sumber ide untuk tata rias fantasi dan tidak hanya berpatokan pada sumber ide atau tema-tema yang kerap dijumpai seperti flora, fauna dan lain-lain. Gali lebih banyak sumber ide yang sekiranya bisa dijadikan menjadi sumber ide atau tema untuk tata rias fantasi itu sendiri.

\section{DAFTAR PUSTAKA}

Agmasari,Silvita.2014. Hakikat Makna Burung Phoenix dalam Tradisi China. Tersedia dalam www.nationalgeographic.grid.id (akses pada tanggal 28 April 2018)

Agmasari,Silvita. 2014. Menyikapi Simbol Teratai. Tersedia dalam www.nationalgeographic.grid.id (akses pada tanggal 27 September 2018)

Arisa, Marifani Fitri. 2014. Pengembangan Tata Rias Tokoh dalam Drama Sunan Panggung. Jurnal Tata Rias vol 3 No 01 Tahun 2014 Universitas Negeri Surabaya

Santosa, Eko dkk. 2013. Seni Teater Jilid 2. Jakarta: Direktorat Pembinaan Sekolah Menengah Kejuruan.

https://id.wikipedia.org/wiki/Asia (diakses pada bulan Februari 2018)
https://id.wikipedia.org/wiki/Mitolog iChina (diakses pada bulan febuari 2018) 